\title{
Limitation of Land Tax Regulations as an Instrument for Land Tenure Management
}

\author{
Andhyka Muchtar ${ }^{1}$ Jamal Wiwoho $^{2}$, Lego Karjoko ${ }^{3}$ \\ ${ }^{1.2 .3}$ Universitas Sebelas Maret \\ Surakarta, Indonesia \\ andhykamuch@gmail.com
}

\begin{abstract}
This study aims to determine: (i) whether the regulation of Land Tax can work as an instrument for structuring land tenure (ii) to find out what prerequisites must be prepared by tax law so that it can work as an instrument for managing land tenure. This study used normative legal research methods. with a conceptual approach (conceptual approach). Legal materials were analyzed qualitatively juridically. The results of the study were that the first tax collection system in Indonesia uses a self-assessment system, but in its implementation there are still problems in the form of shortages in payments based on fiscus calculations (Official Assessment). Second, in creating the land tenure tax law, it can be effective, the land tenure tax regulation must be able to create public trust in the government and tax collection does not only prioritize the interests of state treasury income without considering the socio-economic capabilities of the people.
\end{abstract}

Keywords- Land Tax, Land Tenure, Law Enforcement.

\section{INTRODUCTION}

Land is a basic needs of human life because land provides many benefits for human life. One of the benefits of land for humans is a place to live. As mandated in Article 33 paragraph (3) of the 1945 Constitution which states that the earth, water and natural resources contained therein are controlled by the government and used for the greatest prosperity of the people. The above provisions emphasize that the government has a goal, that is to prosper the people. Realizing the goals of the government, the governmet needs financial sources to be used in realizing its goals, one of the sources of government finance comes from the tax sector. Taxes are mandatory levies without contraachievements that are used for public spending, administration of government, construction of infrastructure facilities, etc. [1] Therefore, taxes collected by the government must be implemented based on the law. As explained by Jamal Wiwoho that every policy implemented by the government must be based on applicable laws, as the theory of legism. [2]

The tax collection is carried out based on forced laws, the Taxation system in Indonesia called Self Assessment. The self-assessment system is a tax collection system that requires taxpayers to actively carry out their tax obligations and rights. [3] In other words, the selfassessment system requires taxpayers to calculate, pay, and self-report the amount of tax owed. [4] As Article 10 (1) concerning Customs for Acquisition of Rights on
Land and Buildings, which states that the collection of taxes on fees for the acquisition of rights to land and buildings is a self-assessment, that is taxpayers are given the trust to calculate and pay their own taxes. With the self-assessment system, it is hoped that the task of tax administration will be more neatly and well structured. [5]

One source of government revenue originating from the transfer of land rights is the Land Income Tax (PPh) and the Tax (Bea) on the Acquisition of Land and Building Rights (BPHTB). Both land taxes must be paid at the time of signing the deed of sale and purchase as a legal act. Problems related to taxes on land originated from the uncertainty regarding the imposition of taxes on the transfer of land rights, especially in the process of buying and selling land. The uncertainty is related to the amount of BPHTB and PPh that must be paid by the parties. This problem occurred during the tax validation process where the fiscus party determined the amount of BPHTB and PPh taxes subjectively on land transfers, which was much higher than the transaction price based on the standard for the imposition of Tax Object Selling Value (NJOP), which of course did not match the transaction value stated in the deed of Sale and Purchase.

The above fact shows that the tax collection system on the transfer of land rights is not in accordance with the self-assessment system adopted, because the Government still considers that the level of taxpayer compliance is still very low. It is proven that there are still many taxpayers in land tenure who report their tax obligations that are not in accordance with the real transaction price. Taxes on land tenure are considered very high, so that the current paradigm of taxes is seen as a frightening thing, that is by paying a nominal amount of money that is quite large and used for the benefit of the government.

In addition to high taxes, the low compliance of taxpayers is also due to the taxpayer's paradigm which is considered a forced obligation as if the taxpayer is the main target of the state for coercion so that taxpayers must comply with the provisions of regulations that are very rigid and normative. Tax compliance is the executor of the obligation to deposit and report taxes that must be paid in accordance with the applicable provisions in taxation. Compliance in question is voluntary compliance, but not forced obedience. To create such compliance, it is necessary to have fairness and openness in applying tax regulations, procedural simplicity, and good and fast service to taxpayers. [6] This paradigm makes taxpayers do not feel that they are being treated fairly but are used 
as targets for government income, for example, regarding the validation process of land tenure taxes related to BPHTB taxes. Sometimes in the payment of BPHTB there is still a difference in the value that is the basis for the imposition of BPHTB between the taxpayer and the fiscus, resulting in underpayment by the taxpayer. The underpayment occurs due to the taxpayer setting the transaction price in the Sale and Purchase Deed (AJB) which is considered not in accordance with the fair price. Even though the Taxpayer has carried out his obligations based on the existing regulations, the transaction price agreed by the parties in the sale and purchase is sometimes canceled by Fiscus on the grounds that it does not match the fair market price, causing taxes to be payable. Sometimes the Fiscus determines the amount of tax only based on the assessment of the Party's own Subjectivity. Whereas if you look at the contents of the Director General of Taxes Regulation Number Per 21/PJ/2019 concerning Procedures for Researching Evidence of Fulfillment of Income Tax Payment Obligations from the Transfer of Rights to Land and Buildings and the Binding Agreement on Sale and Purchase of Land and or Buildings and their Amendments, Article 4 states that that the validation process only matches the documents of the parties and the amount of tax paid based on the transaction value or NJOP and does not instead determine the amount of tax that must be paid. From the problems above, it is as if taxpayers are considered only as the main target for government income. Taxpayers should be treated appropriately, so that a good paradigm must be developed for taxpayers so that the tax is not considered as a burden.

\section{RESEARCH METHOD}

This study used normative legal research methods with a conceptual approach. [7] Arguments were carried out to provide prescriptive in the form of constructions or designs regarding whether or not according to the law based on the facts or legal events from the research results. Data collection was done through secondary data searching. Furthermore, secondary data is analyzed qualitatively juridically.

\section{FINDINGS AND DISCUSSION}

\section{Was the Land Tax Regulation Able to Work as an Instrument for Structuring Land Tenure}

There are problems with the collection of land tenure taxes, that is the imposition of BPHTB taxes as referred to in Article 6 paragraphs (1) and (2) letter a, Law Number 20 of 2000 about amendments to Law Number 21 of 1997 concerning customs for acquisition of land rights and the building, reads the basis for the imposition of duties on the acquisition of rights on land and buildings is the acquisition value of the tax object and the acquired value of the tax object as referred to in paragraph (1), that is buying and selling is the transaction price.
However, in reality people are buying and selling land with a transaction price above the NJOP value, but by the government, both the KPP and the local government consider the transaction value not in accordance with the fair market price, causing taxes to be owed. For example, there are several areas where many local government policies in collecting BPHTB taxes are based on the local government's own subjective assessment of the parties. The subjectivity of determining market prices by the government is carried out in a way that cannot be measured by a clear method or with the applicable rules regarding land tenure tax.

Therefore, it can be assumed that the tax payable that arises is not the result of a Self Assessment System where the Taxpayer calculates, pays, and reports himself the amount of tax owed, but becomes an Official Assessment System where the Government determines the amount of tax owed by the taxpayer. So according to the writers there is an inconsistency in the principles of tax payments by local governments in collecting land tenure taxes. This is what causes public distrust of the government, where in collecting taxes the government prioritizes its own interests by trying to collect as much as possible. Public distrust causes people's dishonesty in paying their taxes.

The government's action above is a discretion that is not justified in good governance, if it is associated with Law Number 30 of 2014 concerning Government Administration Article 22 paragraph 2, as reads every use of Government Official's Discretion aims to: a expedite the administration of government; b. fill legal voids; $c$. provide legal certainty; and d. overcome the stagnation of government in certain circumstances for the benefit and public interest.

Article 24 reads "Government officials who use discretion must meet the following requirements: a. are in accordance with the purpose of the Discretion as referred to in Article 22 paragraph (2); b. do not conflict with the provisions of laws and regulations; c. are in accordance with AUPB; d. are based on objective reasons; e. do not create a Conflict of Interest; and f. are done in good faith".

Fiscus actions above have violated the principles of Good Governance. I Gusti Ayu Ketut Rachmi Handayani, stated that the concept of Good Governance requires the rule of law to be implemented properly. The concept of the rule of law has four characteristics, that are: the enforcement of the rule of law, the enforcement of legal certainty, the creation of a responsive law, and creating consistent, non-discriminatory law enforcement and an independent court. [8]

The action of the fiscus created distrust in people, so that the land tax arrangement could not be effective and functioned as an instrument for structuring land tenure. According to Kirchler in slippery slope theory explains that tax compliance depends on how much the tax authorities can be trusted. Policies to improve voluntary tax compliance depend on the level of public trust in tax authorities, that there is no discrimination in tax collection 
that can harm the public as taxpayers. Taxpayer compliance in paying taxes believes that the tax system is implemented properly by tax officials or tax authorities. This means that even though very high tax penalties are applied, tax compliance will only be created if the public believes that the tax authorities in carrying out their duties will act correctly and fairly. [9]

As stated in the theory of legal effectiveness, according to Antony Allot, that law can be effectively enforced in a country measured in three ways, that is: First, whether the law can prevent someone from doing something that is prohibited. Second, whether the law can work as a fair dispute resolution. Third, is the law successful in becoming a rule that facilitates the needs of people?. [10] From the three benchmarks above, it is clear that the land tenure tax law has not been effective as an instrument of land tenure because we still encounter many problems related to the determination of land tenure taxes between the tax authorities and taxpayers. This means that tax law has not provided a fair dispute resolution and has become a rule that facilitates the needs of people. This can be seen how the land tax is getting higher every year as well as the price of land while the economic capacity of people is not paid much attention.

In particular, the BPHTB tax levied by the local government should think about the people's ability and not be concerned with the local government's revenue alone, although one of the tax functions theoretically works as a budgeter, that is taxes as a source of government funds to finance their expenses, but taxes also have other functions, that is Regulerend that the tax can be used to regulate tax is used as a tool to achieve certain goals that are outside the financial sector. [11]

Fiscus behavior as above will cause the growth of non-compliance by taxpayers. As according to Soekanto concluded that the issue of compliance can be returned to its basics, that is: [12]

1) indoctrination, that is everyone does good behavior because the law wants it.

2) utility, that is someone's actions in accordance with the rules will get the benefit.;

3) habituation, that is a habit occurs because it is done repeatedly, and

4) identification, that is legal compliance will arise because it is based on the needs for social interaction.

\section{Conditions Must be Prepared by Tax Law so that it Can Work as an Instrument for Land Tenure Management}

In practice, the land tenure tax is still considered ineffective. There are still many problems that arise in people related to land tenure taxes. As discussed before, it causes public distrust in the government, where in tax collection the government prioritizes its own interests by trying to collect as much as possible to people. Public distrust causes people's dishonesty in paying their taxes. We can see that there is a difference in the paradigm between expectations and reality in the implementation of land tenure tax collection.

Therefore, new constructive thinking is needed so that in the future it is hoped that a tax law will be created that can work as an instrument for better land tenure management. Jamal Wiwoho proposed two ideas that must be implemented by the government in tax reform in the face of the New Normal, that is, the first to improve administration and policies in the field of taxation. Second, to increase taxpayer compliance by changing people's perceptions of taxes. [13] This opinion can be applied to create a good instrument.

For this reason, in order to develop tax law so that it can work as an instrument for the land tenure arrangement, First, regulations related to the determination of the sale value of tax objects as the basis for imposing land tax are expected to require regulations issued by local governments to be in the form of local regulations and not only in the form of decisions/policies of the head of government. This is done to prevent the rise of local government policies that can monopolize the imposition of land, especially the imposition of NJOP as the basis for calculating the fair price of land value. Because NJOP is a reasonable price standard that is subject to tax in the form of BPHTB and PPH. With the enactment of the regional regulation, there is legislative involvement so that a checks and balances system is created in the form of supervision. Through the Legislative Institution as representatives of the people, they can incorporate the aspirations and interests of the people into the articles of the Act. [14] As stated by William Chamblis and Robert B. Seidman, law in society is influenced by social forces, law-making institutions and law-implementing institutions. Therefore, it is hoped that the law cannot be monopolized by the law itself. [15] Based on an understanding of the workings of law in society, seen from the theory of Chamblis and Seidman, said that the consumer is the target of a rule or law that is connected with the hope of protecting consumers. The existing law is applied to consumers and consumers act as role holders, so that the law as a producer is able to realize consumer protection by acting as a responsible producer. From the theory above, it is clear that the government's policies, both in collecting taxes and increasing the NJOP as a basis for a reasonable land price, must pay attention to the ability of people, so that it is hoped that people will not be burdened by the high tax payment rate based on the NJOP.

Second, the rules regarding the imposition of NJOP as the standard value of a reasonable land price transaction should not be based on the NJOP which is used as the standard for calculating $\mathrm{PBB}$ so that it is difficult to be used as the basis for the transaction price which ultimately causes confusion in the determination of the transaction price in buying and selling so that it cannot be used as a basis for market prices against the selling value land. This creates confusion because on the one hand the NJOP must be lowered for the imposition of PBB fees but on the other hand the NJOP cannot be used 
as a standard for transaction prices because the government considers it very far from a reasonable land price. Therefore, a separation must be made between NJOP as the imposition of Land and Building Tax and NJOP as the basis for imposing a fair land price.

Third, the higher land prices from year to year based on the NJOP are not directly proportional to the Sales Value of Non-Taxable Land Objects (NJOPTKP) which should also be increased so that they are not too burdensome for people. The soaring land price should also be offset by an increase in the Selling Value of Taxable Tax Objects (Non-Taxable Tax (NJOPTKP) so that it will reduce the burden of paying taxes. Every year the price of land increases so that the NJOP as the basis for imposition is also getting higher, but on the other hand, NJOPTKP from year to year has never increased.

Fourth, In the process of collecting land tenure taxes, it must be transparent and easily accessible. The value of transparency and ease of tax collection can be felt in the tax validation process. The Validation process is a series of applications for the acquisition of rights at the Office of the National Land Agency (BPN). Before carrying out the tax validation process, taxpayers are required to obtain a printout in the form of a payment order sheet through online system. The BPHTB Online System can be accessed through the Port of the Regional Revenue Service in each Regional Division, while PPh Payments can be accessed at the DGT Service Port at each Tax Service Office.

In general, the tax validation process takes a long time. In the process of tax validation, there is also often an abuse of authority by the fiscus so that sometimes in the payment of either BPHTB or PPH there is still a difference in the value that forms the basis for the imposition of land tenure tax between taxpayers and fiscus, resulting in underpayments by taxpayers. The underpayment occurred due to the fiscus' assessment of the transaction price setting in the Sale and Purchase Deed (AJB) which was deemed not in accordance with the fair price. Therefore, a new innovation is needed that can make the process of validating land tenure taxes run effectively and transparently and in accordance with the development of an increasingly modern era.

From the explanation above, it is hoped that tax law as an instrument of Land Tenure Arrangement can be effective as explained by Antoni Allot that the law will be effective if the existence of the law can be used as a tool to prevent things that can create instability in an order. The law can be effective if the law achieves its goals as aspired so that the law is made. [16]

\section{CONCLUSIONS}

The tax collection system in Indonesia uses selfassessment taxation, but regarding the collection of land tenure taxes, there are still some problems so that the land tenure tax collection system does not work well. One of the problems that occur in people is related to the sale and purchase of land with transaction prices above the NJOP value, both KPP and local governments, sometimes consider the transaction value not in accordance with the fair market price, so that cause taxes to be payable. Therefore, it seems that the tax payable that arises is not the result of the Self Assessment System, but becomes an Official Assessment System where the Government determines the amount of tax owed by the taxpayer. In creating a land tenure tax law so that it can be effective, new constructive thinking is needed. Therefore, the land tenure tax regulation is expected to create public trust in the government, in collecting taxes does not only prioritize the interests of state treasury income but also consider the socio-economic capabilities of the people.

\section{REFERENCES}

[1] Pranoto, Ayub Torry Satriyo Kusumo, Reformasi Birokrasi Perpajakan Sebagai Usaha Peningkatan Pendapatan Negara Dari Sektor Pajak, Jurnal Yustisia. Vol. 5 No. 2 Mei - Agustus 2016.

[2] Jamal Wiwoho,Lulik Djatikumoro, Dasar-Dasar Penyelesaian Sengketa Pajak, PT Citra Aditya,Jakarta, 2004

[3] Nuramalia Hasanah, Susi Indriani, Efektifitas Pelaksanaan Self Assessment System Dan Modernisasi Administrasi Pajak Terhadap Kualitas Pelayanan Pajak (Studi Kasus Pada Kpp Kebon Jeruk 1) Volume 8, No.1, Tahun 2013, Fakultas Ekonomi, Universitas Negeri Jakarta. 2013

[4] Marihot Pahala Siahaan. 2010, Hukum Pajak Elementer, Graha Ilmu, Yogyakarta,

[5] Istiqomah , 2017, Analisis Kepatuhan Wajib Pajak Orang Pribadi Berkaitan Dengan Adanya Kebijakan Penghapusan Sanksi Pajak, Jurnal Nominal, Volume Vi Nomor 1, Tahun 2017.

[6] Silvani, carlos, 1992, The Economic of tax compliance, Fact and fantasi, National Tax Jurnal

[7] Peter Mahmud Marzuki, Penelitian Hukum, Kencana Prenada Media Group, Jakarta, 2005.

[8] I Gusti Ayu Ketut Rachmi Handayani, 2012, Green Constitution sebagai penguatan norma hukum lingkungan dan pedoman legal drafting peraturan daerah dalam rangka praktik-praktik tata kelola pemerintahan yang baik di daerahhlm. Jurnal Yustisia Vol.1 No.1 Januari - April 2012, Universitas Sebelas maret, 2012

[9] Kirchler, E., Hoelzl, E, and Wahl,I, 2008, Enforced versus voluntary tax compliance: The "slippery slope" framework. Journal of Economic Psychology, 2008.

[10] Diana Tantri Cahyaningsih, 2020, Mengurai Teori Effectiveness of Law Anthony Allot, Jurnal Rechts Vinding Online, ISSN 2089-9009

[11] Munawir S, Pokok-pokok Perpajakan, liberty, Yogyakarta, 1985

[12] Soekanto, Soerjono, Kesadaran Hukum dan Kepatuhan Hukum, Jakarta, CV Rajawali, . 1982

[13] Jamal Wiwoho, 2009, "Reformasi dan Modernisasi Sistem Perpajakaan Nasional dalam Kerangka 
Meningkatkan Kepatuhan Membayar Pajak", dalam Satya Arinanto and Ninuk Triyanti, Memahami Hukum Dari Konstruksi Sampai Implementasi Jakarta, Rajawali Pers, 2009.

[14] Ratnia Solihah dan Siti Witianti, 2016, Pelaksanaan Fungsi Legislasi Dewan Perwakilan Rakyat Pasca Pemilu 2014: Permasalahan Dan Upaya Mengatasinya, Jurnal Ilmu Pemerintahan ISSN 24425958, E-ISSN 2540-8674, CosmoGov, Vol.2 No.2, Oktober 2016.

[15] William J. Camblis dan Robert B. Seidman, Law, Order, and Power, Reading, Mess Addison, Wesly,

[16] Anthony Allot, 10, The Limit of Law, Butterworths, London, 1971 